\title{
Aktifitas Pelajar Yang Bekerja Sebagai Pelayan Kafe Malam Di Desa Pauh Barat Kecamatan Pariaman Tengah
}

\author{
Silvia Nengsih ${ }^{1}$, Erianjoni Erianjoni ${ }^{2}$ \\ 1,2 Universitas Negeri Padang \\ Email: silvianengsih@gmail.com, erianjonisosiologi@gmail.com
}

\begin{abstract}
Abstrak
Penelitian ini bertujuan untuk mengetahui bentuk aktifitas remaja yang bekerja sebagai pelayan kafe malam di Desa Pauh Barat. Teori yang digunakan untuk menganalisis penelitian ini ialah teori yang dikemukakan oleh Talcott Parsons yaitu teori tindakan sosial. Metode yang digunakan dalam penelitian ini ialah pendekatan kualitatif dengan tipe deskriptif serta teknik pemilihan informan snowball sampling. Dalam pengumpulan data dilakukan dengan cara observasi, wawancara dengan teknik analisis data dari Miles dan Huberman. Hasil penelitian ini menunjukkan bentuk aktifitas lain yang sering dilakukan pelajar yang bekerja sebagai pelayan kafe malam di Desa Pauh yaitu, (1). Aktifitas disekolah; (2). kegiatan sebagai pelayan kafe. Pelayanan yang diberikan kepada pelanggan menentukan pendapatan.
\end{abstract}

Kata Kunci: Pelajar, pelayan, pendapatan

Abstract

This study aims to determine the form of activities of adolescents who work as night cafe waiters in West Pauh Village. The theory used to analyze this research is the theory put forward by Talcott Parsons, namely the theory of social action. The method used in this study is a qualitative approach with descriptive type and snowball sampling informant selection technique. In data collection carried out by observation, interviews with data analysis techniques from Miles and Huberman. The results of this study indicate other forms of activities that are often carried out by students who work as night cafe waiters in Pauh Village, namely (1). Activities at school; (2). activities as a cafe waiter. Services provided to customers determine income.

keywords: Students, Servants, Income

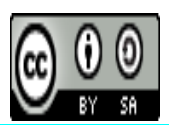

Received: August 1, $2019 \quad$ Revised: August 6, $2019 \quad$ Available Online: August 7, 2019 


\section{Pendahuluan}

Masa remaja adalah masa peralihan dari anak anak menuju dewasa yang mencakup kemantangan mental, emosional, sosial dan fisik. Masa remaja dikenal juga dengan masa yang berpengaruh terhadap proses perkembangan, dimana masa ini sangat membutuhkan perhatian dari berbagai kalangan, terutama lingkungan keluarga. Kehidupan sosial merupakan bagian terpenting dalam perkembangan remaja, meskipun secara badan remaja sudah sempurna, namun dalam proses perkembangan sosial remaja zaman sekarang kuranglah sempurna (Sutarjo, 2014). Perlibatan anak yang masih menempuh jenjang pendidikan dalam dunia pekerjaan merupakan suatu fenomena yang sudah menjadi biasa di kebanyakan negara, baik itu maju maupun negara yang berkembang, ramai dari kelompok remaja yang bekerja hal ini disebabkan karena factor ekonomi, tenaga muda yang terjun langsung dalam dunia pekerjaan merupakan suatu bentuk dalam menambah pendapatan keluarganya, Menurut Malaysia Employment Handbook, seorang anak yang masih sekolah yang mempunyai pekerjaan sampingan yang sesuai dengan kemampuannya dan keupayaannya, hal ini sangat diperlukan perhatian keluarga untuk mengontrol pekerjaan yang dilakukan anak yang mempunyai pekerjaan baik itu pekerjaanya domestic maupu pekerjaan lain, aturan jika seorang anak yang bekerja tidak boleh bekerja lebih dari pada 6 jam dalam satu hari jika anak tersebut yang masih menempuh bangku sekolah. Anak tidak tidak dibolehkan bekerja separuh hari hal ini disebabkan karena anak harus belajar dan menghabiskan banyak waktu di sekolah (Hussin, 2006). Pelajar yang mempunyai pekerjaan sampingan akan berpengaruh terhadap nilai akademiknya, pada dasarnya pelajar yang bekerja lebih mementingkan pekerjaan dibandingkan sekolah (Mardelina, 2017)

Khusus pekerjaan dalam dunia hiburan malam lebih menekankan terhadap pekerjaan yang memberikan pelayanan kepada para tamu baik itu restoran maupun kafe, wanita yang bekerja sebagai pelayan dikenal dengan istilah Waitreess dan bagi laki laki dikenal dengan sebutan Waiter, pada umunya tempat hiburan malam lebih mendominasi terhadap pengunaan tenaga kerja wanita, hal ini disebabkan karena wanita lebih bisa dalam proses atau pengunjung, hal ini disebabkan jenis kelamin peremuan yang dipekerjakan memiliki daya tarik tinggi bagi pengunjung (Susilo, 2016). Karena kondisi ekonomi yang lemah orang yang bekerja tidak memandang jenis pekerjaan yang dia lakukan dan melakukan pekerjaa tersebut dengan semangat tinggi, mereka berkeja untik memperoleh uang masukan, tiap pekerjaan mempunyai kopensasinya, biasanya pekerja hiburan malam lebih menekankan pada suatu tempat dimana terdapat orang orang yang hanya mencari suatu kesenangan, biasanya pekerjaan ini banyak dilakoni oleh orang dewasa, dampak yang akan muncul dari pekerjaan ini yaitu mendapat pandangan yang kurang bagus dari masyarakat umum. Kegiatan tesebut dengan tujuan untuk menghasilkan atau mendapatkan sesuatu dalam bentuk benda atau uang untuk kemajuan dalam kehidupan rill (Indah, 2017). Dengan pertumbahan dan perkembangan zaman yang semakin maju mendorong munculnya berbagai akftitas di luar rumah yang beragam, sehingga pemenuhan kebutuhan seseorang akan pangannya akan sulit untuk terpenuhi, sehingga restoran atau kafe dijadikan sebagai tempat mengkosumsi berbagai makanan siap saji, dimana dapat memenuhi makanan yang ingin dipesan oleh pelanggan (Wulandari, 2015)

Pariaman adalah salah satu kota yang terkenal dengan tempat wisata pantai yang sangat indah dan menarik dengan pantai yang indah dan bersih dan juga dihiasi dengan beberapa jajaran kafe yang sangat unik di sepanjang pantai, selain itu kota ini juga terkenal dengan wisata religi dan adat istidatnya yang masih kental. Seiring dengan perkembangan zaman yang semakin modern dan pergaulan yang bebas banyak dijumpai remaja remaja yang berprilaku tidak sesuai dengan nilai dan norma yang diinginkan masyarakat, salah satunya 
adalah tidak berfungsi secara semestinyaa beberapa kafe di kota ini. Pada dasarnya berdirinya suatu kafe tidak hanya memiliki satu fungsi saja seperti menikmati makanan dan minuman tetapi juga dijadikan sebagai tempat untuk berkumpul dan juga sebagai gaya hidup bagi anak muda untuk meningkatkan penilai dari orang lain (Fauzi, 2017). Salah satunya kafe di Desa Puah Barat, kafe tidak hanya dijadikan sebagai tempat menikmati makanan dan minuman serta sebagai tempat rileks dan berkumpul bersama teman maupun keluarga, tetapi juga ada fungsi lain. Berdirinya kafe di tepi pantai adalah salah satu lokasi yang sangat strategis untuk mendirikan kafe dan juga didukung oleh pemandangan yang indah dan menarik akan mengundang pengunjung dari berbagai kalangan, tapi berbeda halnya dengan beberapa kafe di Desa Pauah Barat Kecamatan Pariaman Tengah, kafe ini lokasinya jauh dari keramaian dan pemungkiman masyarakat. Fungsi dari kafe inipun berbeda dengan kafe lainnya yang tidak hanya menyediakan berbagai aneka makanan dan minuman, tetapi juga memberikan pelayanan khusus kepada pelanggan. Pada dasarnya fungsi kafe yaitu untuk menikmati makanan dan minuman serta tempat untuk santai bersama teman dan keluarga, tetapi sesuai kebutuhan modernisasi kafe tidak terbatas untuk tempat nongkrong anak anak muda, tapi bisa sebagai tempat rapat yang cozy (nyaman), sebagai tempat sarapan Breakfast, dengan makanan cepat saji atau fast food, yang uniknya pada malam harinya, tempat ini malah dibanjiri anak muda, apalagi malam minggu, dikutip dari jurnal (Dimyati, 2009). Di dalam sebuah kafe didukung dengan adanya berbagai pelayan untuk membantu menjalankan visi dan misi kafe tersebut. Dengan pelayan memiliki tugas yang telah ditetapkan. Pelayanan menunjukan segala bentuk aktualisasi kegiatan pelayanan yang memuaskan orang orang yang menerima pelayanan sesuai dengan daya tanggap, menunbuhkan adanya jaminan (assurance), menunjukan bukti fisisk (tangible) yang dapat dilihatnya dan empati dari orang orang yang memberikan pelayanan sesuai dengan kehendak pelanggannya.(Juyandi, 2004). Keberhasilan suatu usaha tergantung kedapa pemberian pelayanan kepada pelanggannya dan juga harga yang membuat loyalitas terhadap pelanggan(Sembiring, 2018). Harga suatu makan dan minuman yang tersedia di suatu kafe atau restoran tidak menjadi faktor terhadap meningkatkan pelanggan, yang sangat berpengaruh terhadap loyalitas pelanggan yaitu pelayanan yang diberikan oleh pelayan dan juga kondisi kafe tersebut yang sangat mendukung(Nggaur, 2018). Peran ganda adalah suatu tugas yang ada pada diri seseorang dimana tugas tersebut dikerjakan dalam waktu bersamaan, disini pelajar yang bekerja sebagai pelayan juga membverikan pelayanan khusus kepada pelanggannya. (Santoso, 2009) Penyelewenggan tugas pelayan dengan adanya peran ganda yang dilakukan oleh pelayan digunakan sebagai daya tarik bagi pelanggan dan juga dijadikan sebagai loyalitas pelanggan bagi pemilik kafe. Dengan tersedianya pelayanan khusus di kafe X membuat kafe ini menjadi incaran bagi kalangan remaja. Pendapatan yang diperoleh oleh pelayan malam yang memberikan pelayanan khusus tergantung kepada pelayanan yang diberikan kepada pelanggannya, akan mendapatkan bayaran banyak atau uang banyak jika pelayan memberikan suatu kepuasan kepada pelanggan yang mengarah ke pemuasan kebutuhan seks laki-laki, semakin pelanggan puas terhadap pelayanan maka akan semakin besar pula uang yang akan didapat seorang pelayan (Purnando, 2017).

\section{Metode Penelitian}

Penelitian dalam penelitian ini menggunakan pendekatan deskriptif kualitatif, yang bertujuan mendeskripsikan realitas yang menjadi pokok persoalan. Tipe penelitian yang digunakan adalah studi kasus yaitu memberikan ganbaran mengenai suatu fenomena (Maleog, 2004), disini peneliti mengambarkan aktifitas pelajar yang bekerja sebagai pelayan kafe malam di Desa Pauh Barat. Pemilihan informan dilakukan dengan menggunakan teknikteknik Snawball sampling, peneliti hanya membutuhkan 1 orang informan, selanjutnya 
informan tersebut nantinya akan menjadi sumber untuk informan berikutnya, peneliti menentukan seseorang untuk menjadi anggota sampel atas dasar rekomendasi atau anjuran orang yang telah lebih dahulu menjadi sampel, dalam hal ini perlu memperhatikan dalam menggunakan dan memilih teknik yang ada (Prof. Sukardi, 2010) Subjek dalam penelitian ini meliputi teman dekat siswi yang bekerja sebagai pelayan kafe malam, masyarakat yang mengetahui pelajar yang bekerja sambilan sebagai pelayan kafe dan pemilik kafe yang menjadi tempat fokus penelitian serta pelajar yang bekerja sebagai pelayan kafe malam di desa Pauh Barat.

Teknik pengumpulan data dilakukan melalui observasi, wawancara dan dokumen. Pengamatan yang dilakukan adalah kegiataan saat menjadi pelayan malam, kemudian melakukan wawancara mendalam dengan pelajar tersebut atau informan yang telah ditetapkan, dalam penelitian ini observasi yang digunakan ialah non-participant observer, di mana peneliti tidak terlibat langsung dengan objek yang akan diteliti yaitu aktifitas yang dilakukan pelajar sebagai pelayan malam yang memberikan pelayanan khusus kepada pelanggan. Pada umumnya observasi ini bersifat terbuka dimana peneliti mengajukan beberapa-pertanyaan umum kepada partisipan yang memungkinkan partisipan bebas memberikan pandangan-pandangan mereka (W. John, 2010). Peneliti juga melakukan wawancara mendalam kepada pelajar yang bekerja sebagai pelayan kafe malam dan juga informan-informan lain yang terkait, meski dalam proses wawancara awalnya tidak terlalu diterima tetapi setelah peneliti maksud dan tujuan untuk melakukan wawancara barulah pelajar yang bekerja tersebut mau diwawancarai.

\section{Hasil dan Pembahasan}

Di Desa Pauah Barat ada tiga kafe X, Y, Z yang berdiri berjajaran di tepi pantai, dimana lokasi kafe ini jauh dari keramaian dan pemukinam warga, Kafe di desa ini memiliki keunikan yang berbeda dari kafe lain khususnya dari segi bagunannya yang sangat nyaman dengan harga yang sangat murah. Bangunan kafe ini berbeda dengan kafe lain dimana kafe ini terkenal dengan bentuk bangunanya yang seperti pondok, seluas satu setengah Meter dan di sekelilingnya dikasih dinding dengan kayu ukuran setenggah meter. Kafe ini sudah berdiri sejak 5 tahun yang lalu, dimana kafe ini didirikan campuran dari biaya pemerintah yang disalurkan pada setiap daerah yang ingin membuka usaha. Kafe X ini menjadi tempat fokus penelitian peneliti, hal ini disebabkan karena kafe ini pada umumya pelayannya banyak dilakoni oleh remaja putri yang masih menempuh bangku sekolah dan juga banyaknya pengunjung yang datang dari berbagai kalangan ke kafe tersebut. Selain bentuk bangunan kafe ini yang bagus dan nyaman untuk bersantai, kafe ini juga dijadikan sebagai tempat pacaran dan juga pemuasan seks laki-laki. Kafe ini berbeda dengan kafe lainnya yang hanya menyediakan makan dan minuman serta dijadikan tempat santai bersama teman maupun keluarga, tetapi juga dijadikan sebagai tempat maksiat bagi para remaja baik itu di siang hari maupun malam hari, Hal ini disebabkan karena tidak adanya aturan yang tegas baik secara tulisan maupun lisan dari pemilik kafenya maupun dari pemuda desa tersebut, sehingga tempat tersebut menjadi incaran bagi kaum muda yang belum menikah untuk memuaskan hawa nafsunya, karena bebas dari aturan inilah yang membuat kafe ini berkembang sehingga bisa mendirikan beberapa pondok lagi. Salah satu cara menarik perhatian pelanggan menurut pemilik kafe di daerah ini adalah dengan dihilangkan aturan dan siapa yang datang bebas melakukan apa saja asalkan jangan sampai tidur kebo, dan juga menyediakan suatu pelayanan khusus di malam harinya sebagai loyalitas pelanggan. Pelayanan di kafe ini juga berbeda dengan kafe lain, dimana pelayanan yang diberikan di siang hari berbeda dengan malamnya. Kafe ini juga menyediakan pelayan khusus kepada pelanggannya. Pelayanan khusus ini 
hanya diberikan di malam hari saja. Pelayan malam pada kafe ini pada umumnya dilakoni oleh remaja putri yang masih menempuh bangku sekolah. Aktifitas yang mereka lakukan ini merupakan suatu tindakan yang bertujuan untuk mendapatkan uang, sehingga dengan bekerja sampingan sebagai pelayan kafe malam mereka mendapatkan uang masukan yang digunakan untuk memenuhi kebutuhan baik itu kebutuhan pokok maupun kebutuhan sekundernya yang belum tercukupi oleh orang tua.Pada dasarnya pelajar yang bekerja di daerah ini didasarkan faktor ekonomi sehingga membuat mereka terjun langsung mencari pekerjaan tampa memilah terlebih dahulu jenis pekerjaan yang mereka kerjakan, di sini orangtua mengetahui anaknya bekerja sampingan tetapi mereka tidak mengetahui jenis pekerjaan yang dilakukan oleh anaknya hal ini disebabkan karena kesibukan orangtua yang membuat kurangnya perhatian terhadap apa yang dilakukan oleh anak di luar sekolah. Dengan adanya pelayanan khusus yang diberikan pada malam hari membuat kafe ini mencari incaran bagi kaum laki-laki terutama bagi anak muda. Pelayanan yang mereka berikan kepada pelanggan selain bertujuan untuk mendapatkan uang juga sebagai daya tarik pelanggan. Stasus sebagai seorang pelajar yang masih duduk di bangku sekolah yang mempunyai pekerjaan sampingan sebagai soerang pelayan tidaklah mudah, dimana pelajar harus bisa menjalankan tugasnya sebagai pelajar di sekolah dan juga sebagai pelayan kafe malam. Di sekolah mereka di tuntut untuk menjalankan aturan yang telah ditetapkan dan menjalankan tugasnya sebagai seorang pelajar, disisi lain dia juga dituntut sebagai pelayan kafe malam. Pelajar yang memiliki pekerjaan sampingan pada umumnya lebih mementingkan kerja dari pada sekolah, hal ini disebabkan karena pola pikir mereka dan pandangan mereka terhadap sekolah akan mulai berkurang, mereka berangapan bahwa lebih baik kerja jelas dapat uang, kalau sekolah tujuannya nanti juga mencari kerja untuk mendapatkan uang juga, kenapa tidak sekarang saja di mulai bekerja. Pada umumnya bagi seseorang yang mempunyai pekerjaan sampingan sebagai pelayan kafe apalagi sebagai pelayan kafe malam, akan mendapat pandangan yang kurang bagus dari teman bahkan dari masyarakat setempat, dan juga akan di jauh dari masyarakat. Masyarakat berangapan bahwa orang yang bekerja di kafe apalagi perempuan pasti mengarah ke jual diri dan juga PSK. Pergaulan juga sangat berpengaruh terhadap perilaku dan tindakan seorang anak yang masih dalam masa perkembangan akan sangat mudah terpengaruh oleh lingkungan yang tidak bagus. Di sini sangat dibutuhkan perhatian atau control dari keluarga untuk mengawasi pergaulan anaknya. Sebagai seorang pelajar yang mempunyai pekerjaan sampingan harus bisa membagi waktu antara waktu untuk belajar dan waktu untuk bekerja, di sini dia memiliki dua status pertama sebagai seorang pelajar yang aktif dan juga sebagai pelayan kafe malam. Aktifitas pelajar yang bekerja sebagai pelayan kafe malam di Desa Pauh Barat dapat kita lihat di bawah ini:

\section{Sebagai Pelajar}

Banyak pelajar yang aktif untuk menempuh pendidikan di samping mereka mempunyai pekerjaan sampingan. Sebagai seorang pelajar yang menuntut ilmu di sekolah harus mematuhi peraturan yang ada di sekolah dan mengikuti proses belajar dan mengajar dengan baik dan tekun, dan melakukan kegiatan yang menunjang bertambahnya ilmu pengetahuan, sehingga pada akhirnya akan memperoleh nilai yang bagus dan mudah untuk melanjutkan pendidikan ke jenjang yang lebih tinggi, tetapi berbeda halnya dengan beberapa pelajar yang bekerja sampingan sebagai pelayan kafe malam di Desa Pauh Barat ini di mana mereka jarang masuk kelas bahkan ada yang tidak datang ke sekolah, mereka sekolah hanya untuk mendapatkan ijazah saja, mereka berfikir kalau sekolah akan membuat mereka mudah untuk mendapatkan pekerjaan. b. Kegiatan Pulang Sekolah. Sekolah adalah tempat menuntut ilmu dari pagi sampai siang bahkan ada yang sampai sore. Biasanya siswi atau pelajar setelah melakukan kegiatan di sekolah dengan adanya proses belajar mengajar membuatnya 
merasakan lelah di mana tidak hanya lelah fisik tetapi juga mengalami lelah otak, di sini pelajar sangat membutuhkan istirahat sepulang sekolah tapi ada ditemukan siswi yang bekerja sepulang Sekolah. Hal ini mereka lakukan untuk menambah pendapatan orang tua mereka dan juga untuk mendapatkan upah agar mereka bisa membeli sesuatu yang mereka inginkan. Pekerjaan yang mereka kerjakan sepulang sekolah ini tidak membuat mereka terikat karena mereka tidak setiap hari bekerja. Pekerjaan yang mereka lakukan pekerjaan domestik seperti sulaman dan ada juga yang mengumpulkan dan menjual kelapa muda.

\section{Sebagai pelayan kafe}

Dalam sebuah kafe biasanya pelayanan sangat berpengaruh terhadap loyalitas pelanggan karena kenyamanan dan pelayanan yang diberikan akan berpengaruh besar terhadap pelanggan dan juga meningkatkan jasa pelayanan yang diberikan akan menambah atau menaiki loyalitas pelanggan. Sebagai pemiliki kafe harus bisa membuat pelanggan tertarik dan datang ke kafenya dengan menyediakan berbagai bentuk pelayanan kepada pelanggannya. Sebagai seorang pelayan tidaklah mudah, butuh suatu keahlian untuk memberikan pelayanan yang bisa menarik perhatian pelanggan.

Seperti di Kafe X yang memiliki dua jenis pelayanan yaitu: a. Pelayan biasa. Sebagai seorang pelayan biasa yang tugasnya seperti tempat kafe atau restoran lainnya, yaitu melayani pelanggan dalam bentuk menghidangkan makanan dan minuman sesuai dengan permintaan pelanggan. dan juga membersihkan tempat tersebut. b. Pelayan plus plus. Sebagai seorang pelayan yang memiliki tugas dua sekaligus tidaklah mudah bagi seorang pelayan, dimana dia harus bisa membagi waktu dan juga bisa membuat pelanggannya merasa senang dengan pelayanan yang mereka berikan. Kegiatan yang mereka lakukan adalah salah satu cara menarik perhatian pelanggan dan juga kegiatan tersebut mereka lakukan untuk mendapatkan tambahan gaji dan menaiki loyalitas pelanggan. Sebagai pelayan kafe malam mereka tidak hanya menghidangkan makanan dan minuman seperti pelayan lain tetapi di sini mereka juga menawarkan jasa pelayanan khusus.

Pelayanan ini tidak semua orang diberikan hanya orang orang yang mau pelayanan khususlah yang akan diberikan pelayanan plus-plus. Semakin bagus dan puas pelangan dengan pelayanan yang diberikan maka semakin besar uang yang akan didapatkan. Pelayanan yang mereka berikan mengarah kepada pemenuhan seks laki-laki, di sini seorang pelayan yang memberikan pelayanan khusus kepada pelanggannya memiliki keistimewaan yaitu mereka bisa menentukan uang yang akan mereka dapatkan pada malam itu, hal ini disebabkan karena gaji pelayan plus tergantung kepada pelanggan. Pada umunya uang yang dia dapat paling rendah Rp. 50.000. per orang.

Pelanggan memberikan imbalan berupa uang yang besar kepada pelayan jika seorang pelayan bisa memberikan kepuasan kepada pelanggannya. Untuk lebih jelas dapat kita lihat bagan di bawah ini gambaran mengenai pelayanan di Kafe $X$ : 


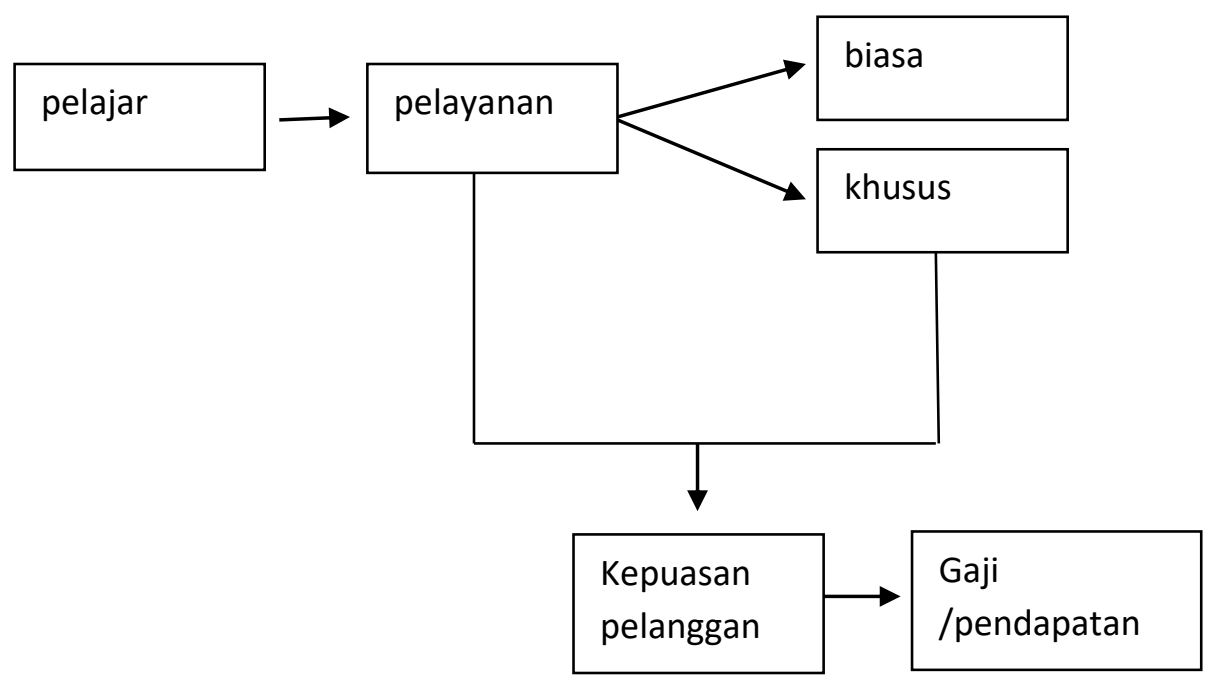

\section{Gambar 1. Pelayanan di Kafe X}

Dari bagan di atas dapat dijelaskan di Kafe X pada umumnya pelayan malam banyak dilakoni oleh remaja putrid yang masih menempuh bangku sekolah. Mereka bekerja sampingan sebagai pelayan kafe untuk mencukupi kebutuhan sekunder mereka. Di Kafe X ini ada dua jenis pelayanan yaitu pelayanan biasa dan pelayanan khusus yang dikenal dengan pelayanan plus-plus. Sebagai seorang pelayan plus, pendapatan yang mereka peroleh selain tergantung jumlah pelanggan tetapi juga pelayanan yang mereka berikan, besar kecilnya gaji yang mereka peroleh tergantung pada kepuasan pelanggan atas pelayanan yang diberikan, jadi pelayanan yang diberikan kepada pelanggan sangat berpengaruh kepada pendapatan atau gaji seorang pelayan. Pelayanan yang mereka berikan berupa pemuasan seks laki-laki, di sini pelayan memberikan sentuhan kepada alat kelamin laki-laki, dan juga boleh melakukan hal yang lain yang bisa membuat pelanggannya puas. Pelanggan Cuma diperbolehkan untuk memberikan umpan balik kepada pelayan asalkan si pelayan mau dan tidak merasa dirugikan.

Berdasarkan hasil observasi peneliti di lapangan, pelayan kafe malam berbeda tiap malamnya dan juga dari segi pakaian pelayan malam pakaiannya cukup terbuka hal ini digunakan sebagai daya tarik pelanggan.

\section{Kesimpulan}

Berdasarkan hasil dari beberapa narasumber yang peneliti wawancarai adalah sebagai berikut: mengenai aktifitas pelajar yang bekerja sebagai pelayan kafe malam, di mana ada dua status yang dimiliki siswi tersebut, pertama sebagai pelajar,di mana sebagai pelajar ada dua bentuk kegiatan yang mereka lakukan, pertama kegiatan di sekolah, pada umumnya mereka Sekolah hanya untuk mendapatkan Ijazah dan mereka mengangap sekolah sebagai syarat yang bisa digunakan untuk mudah mencari pekerjaan, kedua. Kegiatan sepulang sekolah, di mana kegiatan mereka sepulang sekolah bekerja sampingan walaupun pekerjaan tersebut tidak membuat mereka terikat.

Kedua status yang dimiliki siswi yaitu sebagai pelayan, di mana di sini siswi bekerja sebagai pelayan biasa dan juga sebagai pelayan plus plus. Tindakan yang dilakukan siswi tersebut yang menjadi pelayan kafe malam yang mana tindakan tersebut memiliki makna dan tujuan. Pelajar yang bekerja sebagai pelayan kafe malam dengan memberikan pelayanan plus plus kepada pelanggannya dengan tujuan untuk mendapatkan tambahan pendapatannya, yang nantinya akan dia gunakan untuk mencukupi kebutuhan pokok dan kebutuhan sekundernya. 


\section{Daftar Pustaka}

Dimyati, N. S. (2009). Komunitas Kafe Sebagai Gaya Hidup. Skripsi. Retrieved from http://digilib.uin-suka.ac.id

Fauzi, A. (2017). Budaya Nongkrong Anak Muda di Kafe. Jurnal. Retrieved from https://ojs.unud.ac.id

Hussin, S. S. A. (2006). Pelajar Sekolah yang Bekerja Separuh Masa Tinjauan di Kuala Lumpur. Skripsi. Retrieved from http://www.researchgate.net/profile/Sufean Hussin.publication

Indah, R. Y. (2017). Presepsi Masyarakat Terhadap Pekerja Wanita di Tempat Karaoke Syahrini Kota Makasar. Skripsi. Retrieved from http://repository.uin-alauddin.ac.id

Juyandi, H. I. (2004). Kepuasan Pelayanan Jasa. Jakarta: Erlangga.

Mardelina, E. (2017). Pengaruh Kerja Part Time Terhadap Aktivitas Belajar dan Prestasi Akademik Mahasiswa Fakultas Ekonomi Universitas Negeri Yogyakarta. Skripsi. Retrieved from http:/eprints.uny

Nggaur, D. A. (2018). Pengaruh Harga, Suasana Kafe dan Kualitas Pelayanan Terhadap Loyalitas Konsumen dengan Kepuasan Konsomen Sebagai Variabel Moderator. Skripsi. Retrieved from http://eprints.uny.pdf

Prof. Sukardi, P. . (2010). Metodologi Penelitian Pendidikan Kompetensi dan Praktiknya. Jakarta: PT. Bumi Aksara.

Purnando, Y. (2017). Saweran Aktivitas Hiburan dalam Baralek di Nagari Buayan Lubuk Alung. Skripsi. Retrieved from Universitas Negeri Padang

Santoso, H. (2009). Peran Ganda Wanita dan Kesejahteraan. Jurnal, 3(2). Retrieved from Dimensia

Sembiring, A. C. (2018). Meningkatkan Kepuadsan Pelanggan Dengan Mempertimbangkan Kualitas Layanan dan Harga. Skripsi. Retrieved from https://www.researchgatte.net

Susilo, T. (2016). Presepsi Masyarakat Terhadap Perempuan Pekerja Hiburan Malam. Skripsi. Retrieved from http://jurnal.umroh.ac.id

Sutarjo, D. A. P. (2014). Hubungan Antara Interaksi Sosial Teman Sebaya dengan Penerimaan Siswa di SMA Yogyakarta. Skripsi. Retrieved from hhtps://core.ac.uk.pdf

W. John, C. (2010). Research Design Pendekatan Metode Kualitatif, Kuantitatif dan Campuran. Yogyakarta: Pustaka Pelajar.

Wulandari, S. (2015). Kepuasan Konsumen Terhadap Kualitas Pelayanan di Dalam Ngabean Resto. Skripsi. Retrieved from https://eprints.uny.ac.id 